\title{
Peran Manajemen Populasi Anjing dalam Pemberantasan Rabies: Studi Kasus di Desa Pejeng, Kecamatan Tampaksiring, Kabupaten Gianyar, Provinsi Bali
}

\author{
(THE ROLE OF DOG POPULATION MANAGEMENT IN ERADICATION OF RABIES: \\ CASE STUDY IN PEJENG VILLAGE, TAMPAKSIRING DISTRICT, GIANYAR REGENCY, \\ BALI PROVINCE)
}

\author{
Kadek Ari Sindawati ${ }^{*}$, I Ketut Puja ${ }^{2}$, I Nyoman Sadra Dharmawan ${ }^{3}$ \\ ${ }^{1}$ Dinas Ketahanan Pangan, Kelautan dan Perikanan Kabupaten Gianyar, Jl. Astina Sel. No.3, \\ Abianbase, Kec. Gianyar, Kabupaten Gianyar, Bali 80511; ${ }^{2}$ Laboratorium Genetika dan \\ Reproduksi Veteriner Kedokteran Hewan Universitas Udayana, Jl. PB Sudirman, Denpasar, \\ Bali; ${ }^{3}$ Laboratorim Patologi Klinik Kedokteran Hewan Universitas Udayana, J1. PB \\ Sudirman, Denpasar, Bali.*Email:drh.sindawati@yahoo.com
}

\begin{abstract}
Abstrak
Sejak tahun 2008 hingga saat ini rabies masih endemis di Bali. Manajemen Populasi Anjing adalah suatu upaya untuk menstabilkan populasi anjing yang terdiri dari enam komponen yaitu edukasi, legislasi, identifikasi dan registrasi, vaksinasi, sterilisasi, serta manajemen sampah dalam rangka pemberantasan rabies. Program ini telah dilaksanakan di Desa Pejeng, Kecamatan Tampaksiring, Kabupaten Gianyar, Provinsi Bali pada bulan Nopember 2016 yang didanai oleh Food and Agriculture Organization. Penelitian ini bertujuan untuk mengetahui perubahan pengetahuan, sikap dan cara pemeliharaan anjing pada masyarakat di Desa Pejeng setelah penerapan Manajemen Populasi Anjing. Penelitian observasional ini menggunakan cross sectional study melalui pengamatan dan penyebaran kuisioner langsung ke lapangan. Teknik pengambilan sampel menggunakan teknik Probability sampling, Proportional stratified sampling. Jumlah sampel yang diambil 313 responden. Penelitian dilaksanakan pada bulan Nopember 2016 (sebelum Manajemen Populasi Anjing diterapkan) dan pada bulan September 2018 setelah Manajemen Populasi Anjing diterapkan). Data yang terkumpul dianalisis secara deskriptif. Hasil sebelum dan sesudah penerapan Manajemen Populasi Anjing dianalisis dengan analisis non parametrik mengunakan uji Wilcoxon. Berdasarkan hasil penelitian, disimpulkan bahwa Penerapan Manajemen Populasi Anjing secara signifikan $(\mathrm{P}<0,05)$ dapat mengubah pengetahuan, sikap dan cara pemeliharaan anjing pada masyarakat di Desa Pejeng menjadi lebih baik.
\end{abstract}

Kata kunci: rabies; manajemen populasi anjing; pengetahuan; sikap; cara pemeliharaan anjing

\section{Abstract}

Since 2008, rabies is still endemic in Bali. Dog Population Management is an effort to stabilize the dog population consisting of six components: education, legislation, identification and registration, vaccination, sterilization, and waste management in eradicating rabies. This program was implemented in Pejeng Village, Tampaksiring District, Gianyar Regency, Bali Province in November 2016, funded by Food and Agriculture Organization. This study aims to determine changes in knowledge, attitudes and ways of raising dogs in the community in the village of Pejeng after the application of Dog Population Management. This observational study uses a cross-sectional study through observation and dissemination of questionnaires directly to the field. The sampling technique uses probability sampling, a proportional stratified sampling technique with the number of samples was 313 respondents. It was conducted in November 2016 (before the Dog Population Management was implemented) and in September 2018 after the Dog Population Management was applied). The collected data were analyzed descriptively. The results before and after the application of Dog Population Management were analyzed by non-parametric analysis using the Wilcoxon test. Based on the results of this study, it was concluded that the Application of Dog Population Management significantly $(\mathrm{P}<0,05)$ could change knowledge, attitudes and ways of raising dogs in the community in Pejeng Village better than before.

Keywords: rabies; dog population management; knowledge; attitudes; ways of raising dogs 


\section{PENDAHULUAN}

Rabies adalah penyakit virus zoonosis yang mematikan, ditularkan ke manusia melalui kontak (terutama gigitan dan goresan) hewan yang terinfeksi, baik domestik maupun liar, tersebar di semua benua dan bersifat endemik di sebagian besar negara Afrika dan Asia. Rabies diperkirakan menyebabkan setidaknya 55.000 kematian per tahun di seluruh dunia, sekitar 56\% diantaranya terjadi di Asia dan 44\% di Afrika, khususnya daerah pedesaan. Perkiraan biaya tahunan yang dikeluarkan untuk penanganan rabies adalah US $\$ 583,5$ juta, khususnya untuk profilaksis pascapaparan (Post-exsposure Prophylaxis/ PEP). Diperkirakan 10 juta orang di seluruh dunia menerima profilaksis pasca-paparan setelah terpapar hewan yang dicurigai rabies. Sampai saat ini tidak ada pengobatan khusus untuk rabies. Karena itu, pencegahan terhadap rabies merupakan tindakan yang tepat. World Health Organization mempromosikan pencegahan rabies manusia melalui: profilaksis pascapaparan dengan menggunakan vaksin, antirabies imunoglobulin, dan manajemen populasi anjing (WHO, 2001).

Kasus rabies di Bali terjadi bermula di wilayah selatan pulau Bali dan selanjutnya menyebar ke seluruh Bali (Susilawathi et al., 2012). Sejak bulan Januari sampai dengan bulan Desember 2019, tercatat kejadian rabies postif pada anjing sebanyak 230 ekor (Dinas Peternakan dan Kesehatan Hewan Provinsi Bali, 2019). Penyebab belum tuntasnya pembebasan rabies di Bali karena masih banyak anjing yang belum divaksin. Cakupan vaksinasi yang kurang dari target dikarenakan adanya sikap perilaku masyarakat Bali yang membiarkan anjing hidup berkeliaran sehingga populasi anjing yang tidak dapat ditangani semakin banyak. Tingginya populasi anjing diliarkan secara nyata berpengaruh terhadap cakupan vaksinasi. Cakupan vaksinasi yang rendah tidak akan dapat memutus siklus penularan rabies di Bali. Karena itu dibutuhan cara untuk meningkatkan kesadaran masyarakat dalam manajemen pemeliharaan anjing serta pemahaman mengenai kesehatan anjing yang berkeliaran sehingga akan mengurangi penularan rabies.

Pendekatan yang diperkirakan dapat mengatasi kejadian di atas adalah dengan pendekatan yang disebut dengan Dog Population Management (DPM) atau dalam bahasa Indonesia disebut Manajemen Populasi Anjing. Pendekatan ini dilakukan dengan tujuan untuk menstabilkan populasi anjing. Bukti ilmiah dan pengalaman yang telah terbukti dari negara lain tentang Manajemen Populasi Anjing telah menunjukkan bahwa pendekatan yang komprehensif sangat penting untuk menjaga efektivitas kampanye vaksinasi anjing massal, mengurangi wabah rabies secara berkelanjutan dan juga menjamin kesejahteraan anjing dan masyarakat. Dalam jangka panjang pendekatan Manajemen Populasi Anjing juga akan mendorong pendekatan yang lebih bertanggung jawab terhadap kepemilikan anjing (FAO, 2016).

Desa Pejeng merupakan salah satu desa di Bali yang digunakan sebagai desa percontohan pemberantasan rabies melalui pendekatan Manajemen Populasi Anjing. Dalam program ini, ada enam komponen yang diperkirakan efektif di dalam kontrol rabies yaitu edukasi, legislasi, registrasi dan identifikasi, vaksinasi, sterilisasi, dan manajemen sampah. Diharapkan dalam penerapan Manajemen Populasi Anjing ini akan ada perubahan pengetahuan masyarakat, sikap dan cara pemeliharaan anjing agar dapat terhindar dari rabies. Dalam penelitian ini dievaluasi perubahan pengetahuan, sikap dan cara pemeliharaan anjing pada masyarakat Desa Pejeng setelah diperkenalkan program Manajemen Populasi Anjing. 


\section{METODE PENELITIAN}

\section{Rancangan Penelitian}

Penelitian ini bersifat observasional dengan rancangan cross sectional study, Penelitian dilakukan di Desa Pejeng, Kecamatan Tampaksiring, Kabupaten Gianyar, Provinsi Bali. Penelitian dilakukan dua kali yaitu pada bulan Nopember 2016 sebelum program manajemen populasi anjing diterapkan dan bulan September 2018 setelah program manajemen populasi anjing diterapkan.

\section{Pengumpulan Data}

Data berasal dari pengamatan langsung dan wawancara dengan menggunakan kuesioner kepada warga Desa Pejeng. Wawancara dilakukan secara langsung dengan mendatangi rumah-rumah warga di masing-masing banjar yang termasuk sampel penelitian. Jumlah sampel yang diambil sebanyak 313 sampel. Teknik pengambilan sampel digunakan teknik Probability sampling dan proportional stratified sampling.

\section{Analisis Data}

Data yang digunakan merupakan tabulasi dari hasil wawancara dengan menggunakan program Microsoft Excel 2013, kemudian dianalisis secara deskriptif dengan menggunakan program Statistical Product and Services Solution (SPSS.24) for Windows. Hasil sebelum dan sesudah penerapan Manajemen Populasi Anjing dianalisis dengan analisis non parametrik mengunakan uji Wilcoxon.

\section{HASIL DAN PEMBAHASAN}

\section{Hasil}

\section{Karakteristik Responden \\ Sosiodemografi}

Dari 313 responden yang diwawancarai (Tabel 1), rata-rata umur responden adalah 49,27 tahun, umur termuda yaitu 20 tahun dan umur tertua adalah 82 tahun. Jumlah responden laki-laki lebih dominan $(94,89$
$\%$ daripada wanita $(5,11 \%)$. Jumlah anggota keluarga paling dominan yaitu 3 sampai 4 orang $(42,49 \%)$. Tingkat pendidikan responden terbanyak yaitu lulus SMA (48,24\%). Pekerjaan responden terbanyak adalah wiraswasta (26,52\%). Dari segi pendapatan dominan responden memiliki pendapatan $<1,5$ juta/bulan (40,89\%). Tipe rumah responden mayoritas terbatas total tembok $(94,57 \%)$.

\section{Pengetahuan Masyarakat Tentang Rabies Sebelum dan Setelah Diterapkan Manajemen Populasi Anjing}

Rabies sudah tidak asing lagi bagi masyarakat di Desa Pejeng dimana pada tahun 2016 sebanyak 268 responden $(85,62 \%)$ menyatakan pernah mendengar tentang rabies dan pada tahun 2018 meningkat menjadi 308 responden $(98,40 \%)$. Begitu pula responden yang mengetahui bahaya rabies pada tahun 2016 sebanyak 254 responden $(81,15 \%)$ meningkat pada tahun 2018 menjadi 304 responden (97,12\%). Responden yang mengetahui anjing berkeliaran sebagai sumber penularan rabies pada tahun 2016 sebanyak 237 responden $(75,72 \%)$ dan meningkat pada tahun 2018 menjadi 273 responden (87,22\%). Responden yang mengetahui pentingnya vaksinasi rabies pada anjing pada tahun 2016 sebanyak 273 responden $(87,22 \%)$ dan meningkat pada tahun 2018 menjadi 310 responden $(99,04 \%)$. Jawaban responden terhadap cara pencegahan rabies pada anjing pada tahun 2016 sangat beragam, yang menjawab vaksinasi rabies hanya 199 responden $(63.58 \%)$ sementara pada tahun 2018 jawaban lebih homogen dimana responden yang menjawab vaksinasi rabies sebanyak 303 responden $(96,81 \%)$ atau meningkat sebesar 33,23\% (Tabel 2). Data tersebut menunjukkan bahwa Program Manajemen Populasi Anjing berperan nyata $(\mathrm{P}<0,05)$ dalam meningkatkan pengetahuan masyarakat tentang rabies. 
Tabel 1. Karakteristik sosiodemografi responden

\begin{tabular}{|c|c|c|c|c|}
\hline Variabel & Kategori & $\mathrm{N}$ & Frekuensi & Persentase \\
\hline \multirow[t]{6}{*}{ Umur } & 15-24 tahun & 313 & 3 & 0,96 \\
\hline & 25-34 tahun & & 28 & 8,95 \\
\hline & 35-44 tahun & & 88 & 28,12 \\
\hline & 45-54 tahun & & 97 & 30,99 \\
\hline & 55-64 tahun & & 54 & 17,25 \\
\hline & $>65$ tahun & & 43 & 13,74 \\
\hline \multirow[t]{2}{*}{ Jenis kelamin } & Laki-Laki & 313 & 297 & 94,89 \\
\hline & Wanita & & 16 & 5,11 \\
\hline \multirow[t]{4}{*}{ Jumlah anggota keluarga } & $1-2$ & 313 & 13 & 4,15 \\
\hline & $3-4$ & & 133 & 42,49 \\
\hline & $5-6$ & & 123 & 39,30 \\
\hline & $>6$ & & 44 & 14,06 \\
\hline \multirow[t]{5}{*}{ Pendidikan } & Tidak Sekolah & 313 & 9 & 2,88 \\
\hline & Lulus SD & & 64 & 20,45 \\
\hline & Lulus SMP & & 25 & 7,99 \\
\hline & Lulus SMA & & 151 & 48,24 \\
\hline & Perguruan Tinggi & & 64 & 20,45 \\
\hline \multirow[t]{6}{*}{ Pekerjaan } & Petani & 313 & 39 & 12,46 \\
\hline & PNS & & 48 & 15,34 \\
\hline & TNI/Polri & & 7 & 2,24 \\
\hline & Swasta & & 70 & 22,36 \\
\hline & Wiraswasta & & 83 & 26,52 \\
\hline & Lainnya & & 66 & 21,09 \\
\hline \multirow[t]{5}{*}{ Pendapatan } & $<1,5$ juta/bulan & 313 & 128 & 40,89 \\
\hline & 1,5 -3 juta/bulan & & 110 & 35,14 \\
\hline & $>3-5$ juta/bulan & & 62 & 19,81 \\
\hline & $>5-10$ juta/bulan & & 12 & 3,83 \\
\hline & $>10$ juta/bulan & & 1 & 0,32 \\
\hline \multirow[t]{3}{*}{ Tipe Rumah } & Terbatas total tembok & 313 & 296 & 94,57 \\
\hline & Setengah tembok & & 16 & 5,11 \\
\hline & Tidak tertembok & & 1 & 0,32 \\
\hline
\end{tabular}


Tabel 2. Pengetahuan masyarakat tentang rabies sebelum dan setelah diterapkan manajemen populasi anjing

\begin{tabular}{|c|c|c|c|c|c|c|c|}
\hline \multirow{3}{*}{ Variabel } & \multirow{3}{*}{ Kategori } & \multicolumn{3}{|c|}{ Tahun 2016} & \multicolumn{3}{|c|}{ Tahun 2018} \\
\hline & & \multicolumn{3}{|c|}{ Frekuens } & \multicolumn{3}{|c|}{ Frekuens } \\
\hline & & $\mathrm{n}$ & $\mathrm{i}$ & $\%$ & $\mathrm{n}$ & $\mathrm{i}$ & $\%$ \\
\hline \multirow[t]{2}{*}{ Apakah anda pernah } & Pernah & 31 & 268 & 85.6 & 31 & 308 & 98.4 \\
\hline & & 3 & & 2 & 3 & & 0 \\
\hline \multirow[t]{2}{*}{ penyakit Rabies } & Tidak pernah & & 45 & 14.3 & & 5 & 1.60 \\
\hline & & & & 8 & & & \\
\hline \multirow{3}{*}{$\begin{array}{l}\text { Apakah tahu bahaya } \\
\text { rabies }\end{array}$} & Tahu & 31 & 254 & 81.1 & 31 & 304 & 97.1 \\
\hline & & 3 & & 5 & 3 & & 2 \\
\hline & Tidak tahu & & 59 & $\begin{array}{c}18.8 \\
5\end{array}$ & & 9 & 2.88 \\
\hline \multirow{4}{*}{$\begin{array}{l}\text { Apakah tahu anjing } \\
\text { berkeliaran sebagai }\end{array}$} & Tahu & 31 & 237 & 75.7 & 31 & 273 & 87.2 \\
\hline & Tidak tahu & 3 & 76 & 2 & 3 & 40 & 2 \\
\hline & & & & 24,2 & & & 12,7 \\
\hline & & & & 8 & & & 8 \\
\hline \multicolumn{8}{|l|}{$\begin{array}{l}\text { sumber penularan } \\
\text { rabies }\end{array}$} \\
\hline \multirow{4}{*}{$\begin{array}{l}\text { Apakah tahu bahwa } \\
\text { vaksinasi } \\
\text { rabies pada anjing } \\
\text { itu penting }\end{array}$} & Tahu & 31 & 273 & 87.2 & 31 & 310 & 99.0 \\
\hline & & 3 & & 2 & 3 & & 4 \\
\hline & Tidak tahu & & 40 & 12.7 & & 3 & 0.96 \\
\hline & & & & 8 & & & \\
\hline \multirow{8}{*}{$\begin{array}{l}\text { Bagaimana cara } \\
\text { mencegah } \\
\text { rabies pada anjing }\end{array}$} & Vaksinasi rabies & 31 & 199 & 63.5 & 31 & 303 & 96.8 \\
\hline & & 3 & & 8 & 3 & & 1 \\
\hline & Eliminasi & & 20 & 6.39 & & 0 & 0.00 \\
\hline & Lainnya & & 6 & 1.92 & & 1 & 0.32 \\
\hline & Tidak tahu & & 33 & $\begin{array}{c}10.5 \\
4\end{array}$ & & 1 & 0.32 \\
\hline & $\begin{array}{l}\text { Vaksinasi rabies } \\
\text { + eliminasi }\end{array}$ & & 48 & $\begin{array}{c}15.3 \\
4\end{array}$ & & 7 & 2.24 \\
\hline & $\begin{array}{l}\text { Vaksinasi rabies } \\
\text { + lainnya }\end{array}$ & & 5 & 1.60 & & 1 & 0.32 \\
\hline & $\begin{array}{l}\text { Vaksinasi rabies } \\
+ \text { eliminasi + } \\
\text { lainnya }\end{array}$ & & 2 & 0.64 & & 0 & 0.00 \\
\hline
\end{tabular}

Sikap Masyarakat Dalam Upaya Pemberantasan Rabies Sebelum dan Setelah Diterapkan Manajemen Populasi Anjing

Perubahan sikap masyarakat Desa Pejeng dalam upaya pemberantasan rabies sebelum dan setelah diterapkannya
Manajemen Populasi Anjing dapat dilihat pada tabel 3 berikut.

Pada tahun 2016 jawaban responden tentang penanganan pasca gigitan (post exposure prophylaxis) yang tepat yaitu cuci luka dan langsung ke Puskesmas masih rendah $(32,27 \%)$ namun pada tahun 2018 mengalami peningkatan menjadi $88,18 \%$. 
Tabel 3. Sikap masyarakat dalam upaya pemberantasan rabies sebelum dan setelah diterapkan manajemen populasi anjing

\begin{tabular}{|c|c|c|c|c|c|c|c|}
\hline \multirow{2}{*}{ Variabel } & \multicolumn{4}{|c|}{ Tahun 2016} & \multicolumn{3}{|c|}{ Tahun 2018} \\
\hline & Kategori & $\mathrm{n}$ & Frekuensi & $\%$ & $\mathrm{n}$ & Frekuensi & $\%$ \\
\hline \multirow{5}{*}{$\begin{array}{l}\text { Apakah yang } \\
\text { dilakukan } \\
\text { apabila digigit } \\
\text { anjing }\end{array}$} & Cuci luka & 313 & 55 & 17,57 & 313 & 7 & 2,24 \\
\hline & Obat tradisional & & 17 & 5,43 & & 1 & 0,32 \\
\hline & $\begin{array}{l}\text { Langsung ke } \\
\text { puskesmas }\end{array}$ & & 125 & 39,94 & & 0 & 0,00 \\
\hline & $\begin{array}{l}\text { Cuci luka+ obat } \\
\text { tradisional }\end{array}$ & & 15 & 4,79 & & 29 & 9,27 \\
\hline & $\begin{array}{l}\text { Cuci luka + } \\
\text { langsung ke } \\
\text { puskesmas }\end{array}$ & & 101 & 32,27 & & 276 & 88,18 \\
\hline \multirow{2}{*}{$\begin{array}{l}\text { Apa yang harus } \\
\text { diminta ke } \\
\text { puskesmas/ } \\
\text { rumah sakit } \\
\text { untuk mencegah } \\
\text { rabies pada } \\
\text { korban }\end{array}$} & $\begin{array}{l}\text { Suntikan/vaksin/ } \\
\text { serum anti rabies }\end{array}$ & 313 & 257 & 82,11 & 313 & 312 & 99,68 \\
\hline & Tidak tahu & & 56 & 17,89 & & 1 & 0,32 \\
\hline \multirow{5}{*}{$\begin{array}{l}\text { Apa yang } \\
\text { dilakukan pada } \\
\text { anjing yang } \\
\text { menggigit }\end{array}$} & Dibunuh & 313 & 99 & 31,63 & 313 & 19 & 6,07 \\
\hline & $\begin{array}{l}\text { Diikat/dikandang } \\
\text { kan }\end{array}$ & & 37 & 11,82 & & 2 & 0,64 \\
\hline & Lapor petugas & & 136 & 43,45 & & 131 & 41,85 \\
\hline & $\begin{array}{l}\text { Dibunuh + lapor } \\
\text { petugas }\end{array}$ & & 29 & 9,27 & & 45 & 14,38 \\
\hline & $\begin{array}{l}\text { Diikat/dikandang } \\
\text { kan +lapor } \\
\text { petugas }\end{array}$ & & 12 & 3,83 & & 116 & 37,06 \\
\hline \multirow{5}{*}{$\begin{array}{l}\text { Apa yang } \\
\text { dilakukan pada } \\
\text { anjing yang } \\
\text { mengalami } \\
\text { gejala rabies }\end{array}$} & Dibunuh & 313 & 109 & 34,82 & 313 & 13 & 4,15 \\
\hline & $\begin{array}{l}\text { Diikat/dikandang } \\
\text { kan }\end{array}$ & & 21 & 6,71 & & 7 & 2,24 \\
\hline & Lapor petugas & & 145 & 46,33 & & 133 & 42,49 \\
\hline & $\begin{array}{l}\text { Dibunuh+lapor } \\
\text { petugas }\end{array}$ & & 14 & 4,47 & & 41 & 13,10 \\
\hline & $\begin{array}{l}\text { Diikat/dikandang } \\
\text { kan + lapor } \\
\text { petugas }\end{array}$ & & 24 & 7,67 & & 119 & 38,02 \\
\hline \multirow{2}{*}{$\begin{array}{l}\text { Dimana anda } \\
\text { biasanya } \\
\text { membuang } \\
\text { sampah }\end{array}$} & $\begin{array}{l}\text { Pekarangan } \\
\text { rumah }\end{array}$ & 313 & 134 & 42,81 & 313 & 36 & 11,50 \\
\hline & $\begin{array}{l}\text { Tempat } \\
\text { penampungan } \\
\text { sampah }\end{array}$ & & 107 & 34,19 & & 220 & 70,29 \\
\hline \multirow[t]{2}{*}{ rumah tangga } & Kebun & & 34 & 10,86 & & 32 & 10,22 \\
\hline & Lainnya & & 38 & 12,14 & & 25 & 7,99 \\
\hline
\end{tabular}


Dari jawaban responden pada tahun 2016 ada 257 responden $(82,11 \%)$ sudah mengetahui pentingnya Vaksin Anti Rabies/Serum Anti Rabies, dan pada tahun 2018 meningkat menjadi 312 responden $(99,68 \%)$.

Penanganan terhadap anjing yang menggigit yang paling tepat pada tahun 2016 yaitu diikat/dikandangkan kemudian lapor petugas hanya 3,83\% meningkat pada tahun 2018 menjadi $37,06 \%$. Sikap yang dilakukan terhadap anjing yang mengalami gejala Rabies yang paling tepat yaitu diikat/dikandangkan kemudian lapor petugas pada tahun 2016 hanya 7,67\% dan pada tahun 2018 meningkat menjadi $38,02 \%$.

Masyarakat Desa Pejeng pada tahun 2016 berdasarkan hasil survey sebagian besar masih membuang sampah rumah tangganya di pekarangan rumah $(42,81 \%)$ dan pada tahun 2018 masyarakat Desa Pejeng sudah mulai membuang sampah rumah tangganya di tempat penampungan sampah yaitu sebanyak 220 responden $(70,29 \%)$.

Keseluruhan data sikap masyarakat sebelum dan setelah diterapkan manajemen populasi anjing menunjukkan bahwa Program Manajemen Populasi Anjing berperan nyata $(\mathrm{P}<0,05)$ mengubah sikap masyarakat dalam upaya pemberantasan rabies.

\section{Cara Pemeliharaan Anjing Sebelum dan Setelah Diterapkan Manajemen Populasi Anjing}

Berdasarkan hasil survey pada tahun 2016 jumlah responden yang memelihara anjing sebanyak 142 responden (45,37\%). Dari 142 jawaban responden ini dapat dilihat cara pemeliharaan anjing sebelum dan setelah diterapkan Manajemen Populasi Anjing di Desa Pejeng (tabel 4).

Pada tahun 2016 responden yang menjawab anjingnya sudah divaksinasi Rabies sebanyak 124 responden $(87,32 \%)$ meningkat pada tahun 2018 menjadi 140 responden (98,59\%). Dari 142 jawaban responden, cara pemeliharaan anjing di Desa Pejeng dengan cara dilepas sebelum diterapkan Manjaemen Populasi Anjing masih banyak yaitu 100 responden $(70,42 \%)$ menurun pada tahun 2018 menjadi 37 responden $(26,06 \%)$. Jawaban responden yang dapat memegang/menghandle anjingnya pada tahun 2016 sebanyak 136 responden (95,77\%) meningkat pada tahun 2018 menjadi 141 responden $(99,30 \%)$.

Sebelum diterapkan Manajemen Populasi Anjing, cara pemberian makan pada anjing di Desa Pejeng dengan diberikan makan yaitu 135 responden $(95,07 \%)$ meningkat pada tahun 2018 menjadi 141 responden $(99,30 \%)$. Mengenai pergerakan anjing, pada tahun 2016 responden yang menjawab anjing hanya berada di pekarangan rumah sebanyak 83 responden $(58,45 \%)$ meningkat menjadi 100 responden (70,42\%) pada tahun 2018 (Tabel 3). Data ini menunjukkan bahwa Program Manajemen Populasi Anjing berperan nyata $(\mathrm{P}<0,05)$ dalam mengubah cara pemeliharaan anjing dalam upaya pemberantasan rabies.

\section{Pembahasan \\ Pengetahuan Masyarakat Tentang Rabies Sebelum dan Setelah Diterapkan Manajemen Populasi Anjing}

Penyebaran rabies di Indonesia sangat terkait dengan pemahaman, kesadaran, partisipasi dan prilaku masyarakat. Pengetahuan dan pemahaman masyarakat dalam pengendalian dan pemberantasan rabies sangat penting (Saputra et al, 2015). Melepasliarkan anjing, membuatnya dapat berinteraksi dengan anjing lain. Interaksi ini yang menyebabkan virus rabies akan cepat menyebar dari anjing satu ke anjing yang lainnya. Jika ada perkelahian antar anjing dan salah satu anjing adalah hewan pembawa rabies, maka kemungkinan besar anjing yang sehat akan tertular rabies (Gilang, 2015). Kontak antara anjing peliharaan dengan anjing lain merupakan faktor risiko yang berpengaruh signifikan terhadap penularan rabies (Dibia et al., 2015). 
Pada komponen registrasi dan identifikasi dalam Manajemen Populasi Anjing yang diterapkan di Desa Pejeng membuat semua anjing yang merupakan milik warga memiliki kartu identitas dan diberikan tanda berupa kalung dan peneng dengan warna berbeda untuk setiap banjar, sehingga anjing yang dibawa keluar maupun masuk oleh pemiliknya ke dan dari wilayah Desa Pejeng harus melapor ke kantor desa dan ketika ada anjing yang berkeliaran akan segera dapat diketahui identitas dan asalnya.

Strategi pengendalian dan pemberantasan rabies pada hewan umumnya dilakukan dengan kegiatan vaksinasi (Putra, 2012). Hewan Penular Rabies (HPR) yang tidak diberikan vaksin kemungkinan besar akan terjangkit rabies daripada HPR yang telah divaksin (Kardiwinata, 2012). Dalam penerapan Manajemen Populasi Anjing di Desa Pejeng komponen vaksinasi dan sterilisasi untuk anjing dilakukan secara periodik. Sterilisasi dilakukan terhadap anjing liar dan anjing milik warga yang pemiliknya tidak menghendaki penambahan populasi anjing.

Tabel 4. Cara pemeliharaan anjing sebelum dan setelah diterapkan manajemen populasi anjing

\begin{tabular}{|c|c|c|c|c|c|c|c|}
\hline \multirow{2}{*}{ Variabel } & \multirow{2}{*}{ Kategori } & \multicolumn{4}{|c|}{ Tahun 2016} & \multicolumn{2}{|c|}{ Tahun 2018} \\
\hline & & $\mathrm{n}$ & Frekuensi & $\%$ & $\mathrm{n}$ & Frekuensi & $\%$ \\
\hline \multirow{2}{*}{$\begin{array}{l}\text { Apakah anjing sudah } \\
\text { divaksin }\end{array}$} & Sudah & 142 & 124 & 87,32 & 142 & 140 & 98,59 \\
\hline & Belum & & 18 & 12,68 & & 2 & 1,41 \\
\hline \multirow{4}{*}{$\begin{array}{l}\text { Bagaimana cara } \\
\text { pemeliharaan anjing }\end{array}$} & Dikandangkan & 142 & 20 & 14,08 & 142 & 49 & 34,51 \\
\hline & Diikat & & 19 & 13,38 & & 24 & 16,90 \\
\hline & Dilepas & & 100 & 70,42 & & 37 & 26,06 \\
\hline & Lainnya & & 3 & 2,11 & & 32 & 22,54 \\
\hline \multirow{3}{*}{$\begin{array}{l}\text { Apakah anjing dapat } \\
\text { dipegang/dihandle } \\
\text { oleh pemilik }\end{array}$} & Bisa dipegang & 142 & 136 & 95,77 & 142 & 141 & 99,30 \\
\hline & $\begin{array}{l}\text { Tidak bisa } \\
\text { dipegang }\end{array}$ & & 6 & 4,23 & & 1 & 0,70 \\
\hline & & & & & & & \\
\hline \multirow{2}{*}{$\begin{array}{l}\text { Bagaimana cara } \\
\text { pemberian } \\
\text { makan pada anjing }\end{array}$} & Diberikan makan & 142 & 135 & 95,07 & 142 & 141 & 99,30 \\
\hline & $\begin{array}{l}\text { Dibiarkan } \\
\text { mencari } \\
\text { makan sendiri }\end{array}$ & & 7 & 4,93 & & 1 & 0,70 \\
\hline \multirow[t]{3}{*}{$\begin{array}{l}\text { Bagaimana } \\
\text { pergerakan anjing } \\
\text { yang dipelihara }\end{array}$} & $\begin{array}{l}\text { Hanya berada } \\
\text { di pekarangan } \\
\text { rumah }\end{array}$ & 142 & 83 & 58,45 & 142 & 100 & 70,42 \\
\hline & $\begin{array}{l}\text { Kadang-kadang } \\
\text { keluar } \\
\text { berkeliaran }\end{array}$ & & 47 & 33,10 & & 33 & 23,24 \\
\hline & $\begin{array}{l}\text { Berkeliaran di } \\
\text { luar rumah }\end{array}$ & & 12 & 8,45 & & 9 & 6,34 \\
\hline
\end{tabular}


Pada komponen edukasi dimulai dengan pembentukan Kader Bebas Rabies yang beranggotakan 20 orang ibu-ibu anggota Pemberdayaan Kesehatan Keluarga (PKK) yang juga merupakan kader Pos Pelayanan Terpadu (Posyandu), dan Juru Pemantau Jentik (Jumantik). Kader bebas rabies ini diberikan pelatihan untuk dapat menjadi narasumber untuk sosialisasi maupun petugas penanganan kasus gigitan. Selama diterapkannya Manajemen Populasi Anjing Kader Bebas Rabies memberikan sosialisasi kepada warga masyarakat tatkala ada kegiatan kemasyarakatan.

Selain pembentukan Kader Bebas Rabies juga dilakukan pelatihan terhadap para guru sekolah untuk nantinya dapat mensosialisasikan bahaya dan upaya pemberantasan rabies sejak dini kepada anak didiknya. Untuk keberlanjutan sosialisasi di sekolah juga telah dilaksanakan koordinasi dengan Dinas Pendidikan Kabupaten Gianyar untuk memasukkan edukasi rabies ke dalam hidden curriculum. Untuk kalangan remaja juga dilakukan pelatihan terhadap anggota Karang Taruna untuk dapat berkreasi dalam rangka mensosialisasikan bahaya dan upaya pemberantasan rabies yang salah satunya dengan pembuatan ogoh-ogoh yang bertemakan bahaya rabies dan pertunjukan seni berupa Prembon. Dengan pemberdayaan masyarakat ini diharapkan edukasi dapat dilaksanakan secara mandiri dan berkelanjutan.

\section{Sikap Masyarakat Dalam Upaya Pemberantasan Rabies Sebelum dan Setelah Diterapkan Manajemen Populasi Anjing}

Mencuci luka yang terinfeksi rabies dengan sabun dan air dapat meningkatkan kelangsungan hidup hingga 50\% (Radostits et al., 2007). Preferensi untuk pengobatan tradisional mungkin timbul dari banyak faktor termasuk akses mudah ke obat tradisional, kurangnya kesadaran, durasi perawatan yang lama. Ketergantungan pada obat-obatan tradisional dengan kemanjuran yang tidak terbukti sangat berisiko dan tidak ada yang dapat dilakukan untuk menyelamatkan hidup seseorang setelah gejala pertama penyakit tersebut muncul. Setelah dicurigai atau terbukti terpapar virus rabies, penggunaan segera vaksin anti-rabies (VAR) yang efisien dengan manajemen luka yang tepat dan pemberian imunoglobulin rabies secara simultan hampir selalu efektif dalam mencegah rabies (WHO, 2005).

Penanganan anjing yang menggigit sangatlah penting karena terkait dengan ketersediaan data dalam penunjang diagnosa penyakit. Pada umumnya prosedur diagnosa rabies dilakukan jika terdapat laporan kasus gigitan terhadap manusia atau secara potensial terhadap kasus yang menyebabkan rabies (Trimarchi dan Smith, 2002). Untuk memperoleh tingkat akurasi yang tinggi dalam melakukan diagnosa lapangan, cara yang paling tepat adalah dengan memperhatikan riwayat penggigitan, ada tidaknya provokasi dan jumlah penderita gigitan. Penahanan dan observasi klinis selama 1015 hari dilakukan terhadap anjing, kucing yang walaupun tampak sehat dan diketahui telah menggigit orang. Berdasarkan pengalaman di lapangan, anjing yang menggigit lebih dari satu orang tanpa didahului oleh adanya provokasi dan anjing tersebut mati dalam masa observasi. Kemudian specimen otaknya diperiksa di laboratorium hasilnya adalah positif rabies, selanjutnya indikasi kecenderungan rabies di lapangan tanpa adanya tindakan provokasi dapat ditentukan melalui hewan menggigit 1 orang tanpa provokasi kemungkinan (positif) rabies $25 \%$ dan hewan menggigit 2 orang tanpa provokasi kemungkinan (positif) rabies $50 \%$. Sedangkan hewan menggigit 3 orang tanpa provokasi kemungkinan (positif) rabies $75 \%$ dan hewan yang menggigit 4 orang tanpa provokasi kemungkinan (positif) rabies $100 \%$ (Direktorat Jenderal Peternakan dan Kesehatan Hewan,2015).

Dibia et al. (2015) mengemukakan bahwa anjing dengan kondisi yang kurang terawat berisiko terinfeksi rabies tiga kali 
lebih besar dibandingkan anjing yang memiliki kondisi yang prima. Pemilik anjing yang memiliki perhatian yang tinggi pada hewan peliharaannya cenderung mengetahui perubahan tingkah laku lebih dini dari anjingnya apabila menunjukkan gejala sakit (Suartha et al., 2014).

Lokasi dan pengelolaan sampah yang kurang memadai (pembuangan sampah yang tidak terkontrol) merupakan tempat yang cocok bagi beberapa organisme dan menarik bagi berbagai binatang seperti lalat dan anjing yang dapat menjangkitkan penyakit (Yones, 2017). Mengurangi akses ke limbah makanan seperti sampah di jalanjalan, limbah di sekitar tempat pemotongan hewan, toko daging, dan area pasar, dan melindungi tempat pembuangan sampah dari pemulung telah disarankan sebagai cara praktis, murah, dan berkelanjutan untuk mengurangi ukuran populasi anjing yang berkeliaran bebas (Wandeler, 1995). Dengan mulai berubahnya sikap masayarakat Desa Pejeng untuk membuang sampah rumah tangganya dari pekarangana rumah, kebun dan lainnya ke Tempat Penampungan Sampah akan mempermudah perangkat desa untuk mengelola sampah sehingga lingkungan menjadi bersih dan sumber makanan untuk anjing liar menjadi berkurang dan nantinya akan dapat mengurangi populasi anjing liar di Desa Pejeng.

\section{Cara Pemeliharaan Anjing Sebelum dan Setelah Diterapkan Manajemen Populasi Anjing}

Pemahamam pemilik anjing terhadap pencegahan terjadinya penyakit rabies secara tidak langsung dapat dilihat dari kondisi fisik anjing peliharaan mereka, perhatian untuk memberikan pakan, tindakan vaksinasi, ada atau tidaknya pemeliharaan HPR lainnya selain anjing, pemeriksaan kesehatan, jumlah anjing yang dipelihara, pernah berkontak dengan anjing lainnya, jenis pakan yang diberikan, dan cara pemeliharaannya. Pencegahan terhadap penyakit rabies pada anjing perlu didukung oleh cara pemeliharaan anjing yang benar dan baik. Bila mengenal anjing dengan baik, anjing akan sangat bermanfaat dan menjadi teman setia serta mudah dalam pemeliharaannya (Nugraha et al., 2017).

Penerapan komponen legislasi dalam Manajemen Populasi Anjing yaitu dengan dibuat dan diberlakukannya perarem telah mengubah cara pemeliharaan anjing masyarakat di Desa Pejeng dari dominan dilepasliarkan menjadi dikandangkan atau diikat. Hal ini sesuai dengan hasil penelitian Prayoga (2018) yang menyatakan bahwa pemberlakuan perarem mengenai pemeliharaan anjing dan penyakit rabies menunjukkan adanya perbedaan prilaku masyarakat dari segi cara pemeliharaan, mobilitas dan penanganan kesehatan anjing. Selain itu juga ada perbedaan prilaku masyarakat pada pemberian vaksinasi dan penanganan kasus gigitan apabila dibandingkan dengan desa yang tidak memiliki perarem. Masyarakat menjadi tanggap dalam pemeliharaan anjing karena adanya aturan yang mengikat mereka dan adanya sanksi apabila tidak melakukan hal tersebut. Perarem dapat diartikan sebagai keputusan-keputusan paruman (rapat/pertemuan) yang mempunyai kekuatan mengikat, yang kemudian disepakati untuk dijalankan sebaik-baiknya (Parwata, 2007).

Dengan meningkatnya jumlah anjing yang dapat dipegang/dihandle pemiliknya maka akan mempermudah petugas kesehatan hewan untuk memvaksinasi maupun melakukan penanganan kesehatan lainnya termasuk surveillance. Menurut Murphy et al. (2007) bahwa jenis pakan yang baik memengaruhi status kesehatan hewan. Kondisi anjing dengan gizi yang cukup dan terawat dengan baik memacu komponen sistem imun berkembang dengan sempurna sehingga dapat berfungsi secara optimal. Nutrisi anjing dapat menyebabkan rendahnya respons imun. Hewan dengan defisiensi protein atau defisiensi asam amino tertentu 
menyebabkan hewan tersebut lebih peka terhadap infeksi virus.

Mobilitas anjing dan asal anjing yang dipelihara merupakan suatu faktor yang berisiko dalam penularan rabies. Anjing yang didapat dari luar desa terutama desa tertular tanpa diketahui status kesehatan anjing yang diintroduksi dapat berisiko menularkan rabies di daerah yang bebas rabies. Anjing yang diperoleh dari luar desa bisa saja anjing yang berasal dari daerah tertular rabies dan kemungkinan masih dalam masa inkubasi pada saat dibawa ke desanya (Nugraha et al., 2017).

\section{SIMPULAN DAN SARAN}

\section{Simpulan}

Penerapan Manajemen Populasi Anjing secara signifikan $(\mathrm{P}<0,05)$ dapat mengubah pengetahuan, sikap dan cara pemeliharaan anjing pada masyarakat di Desa Pejeng menjadi lebih baik.

\section{Saran}

Penerapan Manajemen Populasi

Anjing perlu dilakukan diseluruh wilayah Provinsi Bali untuk mendukung percepatan Program Bali bebas rabies.

\section{UCAPAN TERIMAKASIH}

Pada kesempatan ini penulis menyampaikan terimakasih kepada Food and Agriculture Organization (FAO) yang telah mendanai penelitian ini. Perbekel, Kader Bebas Rabies Desa Pejeng serta masyarakat Desa Pejeng yang telah membantu dalam pelaksanaan penelitian.

\section{DAFTAR PUSTAKA}

Dibia IN, Sumiarto B, Susetya H, Putra AAG, Scott-Or. 2015. Analisis faktor risiko kasus rabies pada anjing di Bali. Buletin Veteriner. (XXVII):86.

Dinas Peternakan dan Kesehatan Hewan Provinsi Bali. 2019. Laporan Kasus Positif Rabies dari Bulan Januari sampai dengan Bulan Agustus 2019. Gianyar. Bali.

Direktorat Jenderal Peternakan dan Kesehatan Hewan. 2015. Pedoman
Pengendalian dan Penanggulangan Rabies. Jakarta.

Food and Agriculture Organizations (FAO). 2016. Terms of Reference Initial Phase Implementation Dog Population Management Programme Pilot Project to Optimize Rabies Eradication in Bali.

Gilang GIKR. 2015. Analisis dan faktor risiko yang berhubungan dengan gigitan anjing rabies di Provinsi Bali Tahun 2013. Tesis. Denpasar: Universitas Udayana.

Murphy FA, Gibbs EPJ, Horzinek MC, Studdert MJ. 2007. Veterinary Virology. $3^{\text {rd }}$ Ed. London UK. Elsevier Academic Press. Pp. 277-291

Nugraha EY, Batan IW, Kardena IM. 2017. Sistem pemeliharaan anjing dan tingkat pemahaman masyarakat terhadap penyakit rabies di Kabupaten Bangli, Bali.Jurnal Veteriner.18(2): 274-282.

Parwata AAGO. 2007. Memahami awigawig desa pekraman, dalam I Ketut Sudantra dan A.A Gede Oka Parwata (ed): Wicara Lan Pamidanda, Pemberdayaan Desa Pakraman dalam Penyelesaian Perkara di Luar Pengadilan, Upada Sastra Denpasar.

Kardiwinata MP, Sutarga M, Subrata M, Suariyani NLP. 2012. Sistem pemeliharaan anjing sebagai salah satu hewan penular rabies pada penderita rabies di Provinsi Bali tahun 2011. Indonesia J. Pub. Health. 1(1): 50-54.

Prayoga IMA. 2018. Perarem menstimulasi masyarakat untuk memelihara anjing dengan baik sebagai upaya penanggulangan rabies di Bali. Tesis. Denpasar: Universitas Udayana.

Putra AAG. 2012. Bali belum bebas rabies. 4500 gigitan anjing per-bulan. rilis pidato ilmiah dies ke-66 Fakultas Kedokteran Hewan UGM, https://ugm.ac.id/id/berita/45234500.gi gitan.anjing.per.bulan.bali.belum.bebas .rabies.

Radostits OM, Gay CC, Hinchcliff KW, Constable PD. 2007. Veterinary medicine: a textbook of the diseases of 
cattle, horses, sheep, pigs and goats. $10^{\text {th }}$ Ed. London. Saunders. Pp. 1384-1394.

Saputra IGNAWA, Dibia IN, Puja IK. 2015. Faktor risiko dan penyebaran spasial rabies di Bali pada Tahun 2014. J Ilmu Kesehatan Hewan. 3(2): 69-72.

Suartha IN, Anthara MS, Dewi NMRK, Wirata IW, Mahardika GNK, Dharmayudha AAGO, Sudimartini LM. 2014. Perhatian pemilik anjing dalam mendukung Bali bebas rabies. Buletin Veterner Udayana. 6(1): 87-91.

Susilawathi NM, Darwinata AE, Dwija IB, Budayanti NS, Wirasandhi A, Subrata K, Mahardika GNK. 2012. Epidemiological and clinical features of human rabies cases in Bali 2008-2010. BMC Infect. Dis. (12):81.

Trimarchi CV, Smith JS. 2002. Diagnostic Evaluation. In: Jackson AC, Wunner WH. Rabies. London, UK: Elsevier Science (USA), Pp. 308-344.
Wandeler AI. 1995. Ecological and epidemiological data requirements for the planning of dog rabies control. In: Kuwert EM, Koprowski CH, Bögel K, editors. Rabies in the Tropics. Berlin, Heidelberg: Springer-Verlag. Pp. 65761.

World Health Organization (WHO). 2001. WHO recomended standards and strategies for surveillance, prevention and control of communicable diseases. http://apps.who.int/iris/bitstream/handl e/10665/67088/WHO_CDS_CPE_SM T_2001.13.pdf;jsessionid=D8ECE253 F46CE7193762AAD3A8018F2A?sequ ence $=1$

World Health Organization (WHO). 2005. WHO expert consultation on rabies first report. WHO Technical Report Series 931. Geneva, Switzerland. Pp. 1-121.

Yones I. 2007. Kajian Pengelolaan Sampah Di Kota Ranai Ibu Kota Kabupaten Natuna Propinsi Kepulauan Riau. Universitas Diponogoro. Semarang. 